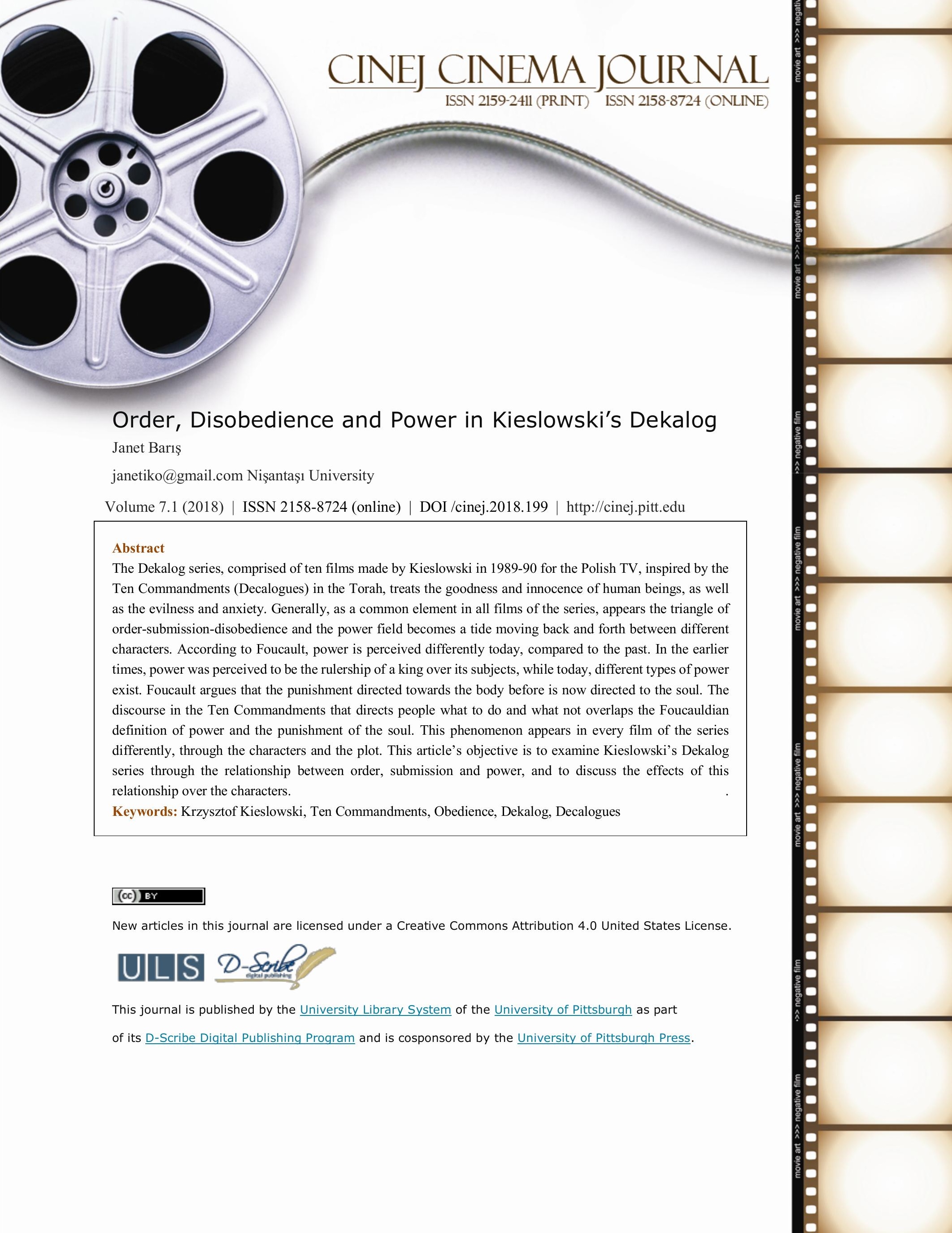




\title{
Order, Disobedience and Power in Kieslowski's Dekalog
}

\author{
Janet Barış
}

\section{Introduction}

Krzyzstof Kieslowski, in his one-hour long Dekalog series that he made for the Polish TV in 1989-1990, takes the Ten Commandments (Decalogues) as the reference point. These commandments that are believed to be revealed to Moses and written by God direct people what to do or what not in life. The principal issue that Kieslowski's Dekalog revolves around is the human itself, along with its weaknesses and inner struggles.

In all of the ten stories, the obedience-disobedience processes through the Ten Commandments appear differently; and the inter-character relationships show resemblances to the Foucauldian conception of power, discourse and obedience. In each story, these resemblances take a different shape. The reactions, reflexes and behaviors of the characters in the conditions they are in move around the power and discourse field conceptualized by Foucault.

The Ten Commandments that are believed to be revealed to Moses about 2500 years ago were issued as scriptures. These written directions appear to be an indication of the power of religion over people. Lefebvre, questioning the role of everyday life in modernity, also refers to Writing (Lefebvre, 2007).

When Moses descended from Mount Sinai and set up before the Children of Israel the Tables of the Law written by the finger of God, he created the eternal Father; centuries were founded on his gesture and on its verbal commentary, the holy narrative that justified it. He was the founder and his mystification became the truth. These tables of principles owed their longevity to the holiness of their inscription, and the faithful would never doubt that they would last until the end of time. Moses was certainly indebted to a superior civilization for his understanding of the 
virtues attendant to the written word; before the artless Bedouin whom he was leading to their great historical fate he performed an action that was both magical and pre-eminently functional. Hard and cold, stone was the perfect symbol of the Writing's timelessness, of its permanence and (apparent) definitiveness, and thus of its trans-historicity. The Writing is anti-word ; once God had written prior to time and for all time, he was silent, and his representatives would be reduced to interpreting and commenting on the Tables of the Law, while others would question their validity, thus giving rise to the conflict between speech and writing, between the Spirit and the Letter. (Lefebvre, 2007, p.154).

The Polish-born director Krzystof Kieslowski, with the Dekalog series that he interpreted the commandments through principles contributed to this commentary with ten medium-length films.

The Ten Commandments, according to the Jewish faith, are a set of religious and moral principles that are believed to be given to Moses in Mount Sinai as two stone tablets. These commandments are; 1) Thou shalt not have other gods before me, 2) Thou shalt not make unto thee any graven image... Thou shalt not bow down thyself to them, nor serve them, 3) Thou shalt not take the name of the Lord thy God in vain, 4) Remember the Sabbath day, to keep it holy, 5) Honor thy father and thy mother, 6) Thou shalt not kill, 7) Thou shalt not commit adultery, 8) Thou shalt not steal, 9) Thou shalt not bear false witness against thy neighbor, and 10) Thou shalt not covet thy neighbor's wife and goods.

Kieslowski states that the ten stories that constitute Dekalog do not aim to reflect the commandments directly. According to him, the protagonists of the stories face situations that can be interpreted differently from different angles, and at the end it becomes apparent that it is 
impossible to abide by the commandments due to these innumerable options (Taşçıyan, 1997, p.114).

According to Joseph G. Kickasola, Kieslowski's Dekalog idealizes the Ten Commandments through living people and it is not always happy, easy or completely perceivable. Meanwhile, people learn a life lesson from these commandments. In Kieslowski's shaped judgement, there is also a path to metaphysical themes (Kickasola, 2016, p.42).

All the characters in Dekalog find themselves in moral dilemmas, and suffer because of them. Even though the rule of the Ten Commandments seems to prevail in these films, actually Kieslowski does not establish a structure that complies with the commandments; he shows the disobedience and how it becomes a means of power over the characters, by not confirming the commandments, but by questioning them instead. He also invites his viewers to question these commandments.

There is a deep connection between religious belief, sufferance and the pain experienced in daily life. According to Le Breton, analyzing the relationship between pain and religion based on Holy Scriptures, argues that in the Holy Writ tradition (Torah and the Bible), disease and pain emerge after Adam and Eve are deceived by the serpent and eat the fruits of the tree of good and evil; "Human does not know pain in the beginning. Pain is a consequence of the emergence of conscience. Human separating from the God are now responsible for their own fate. Unhappiness is the consequence of the separation between the human and the divinity" (Le Breton, 2005, pp.7375).

Kieslowski's Dekalog focuses on human weaknesses, and shows how the power relationships between the characters play a role in obedience or disobedience to the Ten Commandments. The fact that the director takes the Ten Commandments as reference does not 
mean that he approves them. On the contrary, he puts them under question and narrates the darkness caused by the commandments in human lives.

The main objective of this article is to compare the order-obedience relationship with the power relationships described by Foucault, and to discuss the characters through the orderobedience-disobedience relationship in modern life and the consequences of not abiding by the order.

\section{Foucault and Power in Everyday Life}

The ways of ruling under feudal order and in modern life differ. In modern life, power displays itself through its supervisors, and establishes an institutional surveillance mechanism that supervises the supervisors. According to Foucault It is a question of situating the techniques of punishment - whether they seize the body in the ritual of public torture and execution or whether they are addressed to the soul - in the history of this body politic; of considering penal practices less as a consequence of legal theories than as a chapter of political anatomy (Foucault, 1995: 28).

Power is usually considered to be a "thing" that is possessed by an actor or a set of actors to be exerted over others deliberately. Meanwhile, Foucault defines power over "power relationships." These relationships cannot be associated to a single source or system. Power is not a "commodity" to be possessed or obtained. Also, power cannot solely be considered to be the sovereignty of a political entity over its subjects. According to Foucault, the issue loses its importance when power is merely translated to executive or constitutional vocabulary or to the state and state apparatuses. Power is a complex, intense and common thing that operates differently than a set of laws or a state. "Foucault does not see the power to be solely possessed, he considers it to be something positive and to be exerted. According to him, power cannot be associated with 
intermediaries and interests, but with countless practices" (Canpolat, 2003, p.98). Foucault's conception of power carries it beyond a political term, reaching to a whole new dimension.

Foucault emphasizes on how power is constituted, rather than what it is. Power is the one to define "things," dictates desires, shapes knowledge and produce discourse. In other words, power may shape body, taste, life and sense.

According to Foucault, in all human relationships, regardless it is a communication or love relationship, an institutional relationship or an economic one, power is always there. To speak about the mechanism of power is to speak about a wide and long bridge featuring "their actions and attitudes, their discourses, learning processes and everyday lives" (Foucault, Prison Talk, p.39) Because, the economic transformation of the $18^{\text {th }}$ century dictated that power should circulate its impact using finer channels to individuals, their bodies, attitudes, and even their all everyday actions. Therefore, power, even though it is exerted to many people, can be as efficient as if it is exerted over a single person. According to Foucault, what is important is to grasp the power where it becomes capillary, in its final frontiers, after it circulated and expanded, and when power exceeds beyond the rule of law which regulates and restricts it, internalized within institutions and materialized within practices (Foucault, 2003, p.41). Foucault challenges the idea that power is wielded by people or groups by way of 'episodic' or 'sovereign' acts of domination or coercion, seeing it instead as dispersed and pervasive. 'Power is everywhere' and 'comes from everywhere' so in this sense is neither an agency nor a structure (Foucault, 1998: 63).

Kieslowski's Dekalog feature a divine belief as they are based on Moses' commandments. Meanwhile, while treating these commandments, Kieslowski does not have a divine or religious regard. Treating his characters, he shows how the order-obedience-disobedience triangle displays itself and it presents the characters a field of power. 


\section{Dekalog: Order, Obedience and Power}

In each Dekalog, we come across a different order-obedience relationship. This relationship is also a harbinger of a great challenge for the character. In the first episode that is based on the "Thou shalt not bow down thyself to any graven image" commandment, a father-son relationship is shown. Father Krzysztof is a scientist, and his will and choices are fulfilled by his unquestionable trust in science. Son Pawel asks him questions about death throughout the episode. Meanwhile, the father wants his son to grow up someone trusting in science as himself. He is not sure about taking him to the church either.

The film gains its real momentum when the father calculates the breaking rate of the ice and decides that his son may ice skate. After the father asks his son to call the meteorological center to ask about the weather in the next three days and analyses these data on the computer, he sends his son to skate in peace, and the things take a turn. The course of events led by computers and sciences, overshadowing religion comes to an end when Pawel goes skating and never comes back.

When the Ten Commandments urge "not to bow down to any graven image," they underline the choice on a single deity; God or science, but especially God. Obviously, that single

deity refers to God, not to science. Scientifically, it was deemed safe to send the child to skating but the ice still broke. The child's death upon the ice breaking is about things that only God may know, and not the science. However, this fact does not keep from rebelling against God. Kieslowski questions the single deity and its supreme being over the father going to the church to have a face off with God. 
"I think one is hit by waves, and that one starts out the day with an aim, a project, a plan, and finds oneself foiled. One finds oneself fallen. One is exhausted but does not know why. Something is larger than one's own deliberate plan, one's own project, one's own knowing and choosing.” (Butler, 2004, p.21).

The father sends his child on the light of scientific knowledge. He abides by the power of the "knowledge," but he loses. According to Foucault, power and knowledge are two faces of the same thing and they include each other directly (Larrain, 1995, p.31). In Foucault's power, the knowledge is not neutral or objective. In other words, knowledge is political as its presence depends on power relationships.

Foucault's discourse of power can be seen both in the father-son relationship and when the father has to face the consequences of his own mistake. According to Foucault, power is everywhere, and here, there is a power relationship stemming from the everyday life depending on the father-son relationship. The son goes skating trusting in the dependability of this power, yet he dies.

In the end, there is a deep and sharp pain. The father will not be penalized per se, but his moral pain will still put him in some sort of "punishment." According to Foucault, the new kind of punishment takes an aim at soul, rather than body; the pain the father experiences is the pain directed to the soul, in Foucauldian terms. The soul is the prison of the body and in modernity, souls are imprisoned.

The second episode of Dekalog is based on the "Thou shalt not take the name of the Lord thy God in vain" commandment. The story of Dorota, whose husband has cancer and who tries to find her doctor neighbor to learn if her husband would live or not, is told. Whether her husband lives or not is crucial to Dorota, because she carries somebody else's baby. Her decision on keeping the baby depends on if her husband lives or not. 
The doctor is pessimistic from the beginning. When he tells Dorota that her husband would die, she wants to make sure and asks the doctor to swear in the name of God. The doctor swears, and the woman decides to give birth to the child.

There is an inner conflict from the beginning to the end. The woman carries a guilty conscience, as well as a baby. In a moment when she is not sure of life or death, she kills all the flowers in her house. Meanwhile, her husband in the hospital is weak, he has to rest all the time, and he has no willingness to live. However, at the end of the film, on the contrary to the doctor's prediction, he lives on. Dorota decides against abortion thinking her husband would die, yet he stays alive.

Kieslowski associates the "Thou shalt not take the name of the Lord thy God in vain" commandment with the moment when the doctor swears in the name of God that the husband would die. The doctor swears confidently, and as a result, Dorota changes her mind on abortion. The commandment revealed to Moses was not respected, the name of God was mentioned on an unsure matter. Yet, this disobedience does not result in a disaster, on the contrary, it leads to the birth of a child.

At this point, the power given to the doctor by the society appears to be important. While the film is based on the events happening to the other characters, the deciding character is the doctor, and throughout the film, we see him shaping his power through other characters. That is to say, there may be a 'knowledge of the body that is not exactly the science of its functioning, and a mastery of its forces that is more than the ability to conquer them: this knowledge and this mastery constitute what might be called the political technology of the body. (Foucault, 1995:22). Foucault is concerned with the underlying archaeological structures of knowledge (savoir). But the principle is the same in both cases: the mere fact that a cognitive state is an effect of power does not exclude 
it from the realm of knowledge. Power and knowledge are logically compatible (Gutting, 2005: 53) The doctor, as an institutional and dependable figure, gives false information, and affects the woman's decision. He renders his field of power to domination, and he was not contested since he used his institutional status.

The third Dekalog is based on the commandment that urges not to work on the holy Sabbath day. In the Christmas Day, Janusz, who is supposed to stay at home with his wife and child, finds himself in a dilemma when his ex Ewa comes around. Ewa's husband goes AWOL, and she needs Janusz's help to be able to find him. Janusz goes with Ewa, after telling his wife that his cab is stolen. Through the night, they check the hospitals and the train stations, hoping to find Ewa's husband. The search also leads to revisiting love, lies, the past, betrayal and loyalty. After the sun comes up, Ewa comes clean about the truth. Her husband left him three years ago and went to Krakow, and the real reason Ewa called Janusz is not to be alone in the Christmas night and spend the night with him. Had Janusz not shown up, maybe she would have taken sleeping pills and committed suicide.

According to Zizek, we have difficulty in recognizing and identifying the characters in Dekalog 3. Even though we are finally aware of the sad situation of Ewa, we can not have compassion for her. Dekalog perhaps is the only one which does not emotionally connect the audience due to its ill-disposed attitude towards characters. (Zizek, 2009, s, 13).

Kieslowski again tackles one of the commandments, and shows that working on a holy day may touch two people's lives in different ways. Bearing in mind the factors that keep Ewa and Janusz together for a night, we do not observe an emotional distance to the viewer like the one that Zizek suggests.

Here, the power relationship is built upon the "discourse." Ewa tells a lie and Janusz trails behind. Foucault's approach to the discourse and power tries to explain how language, creating 
and regulating sense, helps social institutions produce individuals and turn them into submissive bodies. In his view, with the production, accumulation, circulation and function of discourse, power relationships cannot be positioned, reinforced and produced. Foucault argues that modern concepts such as human, soul, individual, and human sciences are actually products of the discourse of power that aim to control human body (Canpolat, 2003, p.106).

In Dekalog 4, a father and daughter's confrontation (or lack thereof) with their own reality is told. In this film based on the "honor thy father and thy mother" commandment, initially a typical father-daughter relationship between Anka and Micha is shown. There is no mother, and father Micha has to travel for business all the time. In one of these business trips, Anka finds a letter at home. The letter is from her mother, and it is written that she should open it only after her father dies. The next day, she goes to the airport to pick up her father, and makes him read aloud this letter which tells he is not actually her real father.

From this moment on, the situation is a major questioning both for Micha and Anka. Is their relationship merely a father-daughter relationship, is the fact that the father is jealous of her boyfriends merely a fatherly jealousy? At this point, Anka expresses her feelings more openly. This process will either lead to the relapse of those buried for years, or to be buried even more forever.

The real surprise is that the letter that the father read aloud at the airport is actually written by Anek herself. The letter is still a mystery. There are two ways of getting rid of this mystery; either destroying it or making it last forever by reading it. We see the letter burning, the only legible phrase is "Micha, there is a truth that I should tell you about," we cannot see the rest of it. Who Micha really is, whether he is the real father or not remains to be a mystery, burned to flames. Micha and Anka continue to live their own realities. 
The "honor thy father and thy mother" commandment is reversed in this Dekalog. Because it is obscure if the father is a real father or an object of desire for the girl. It is also unknown whether the man that the girl knows as her father is her real father or not.

There is a father-daughter relationship, yet this relationship is also uncertain. Between the father and daughter, there is an unrevealed truth, a "forbidden word." According to Foucault, in modern times, the discourse itself or its production is somehow controlled. Not everything may be discussed by everyone. "The object being a taboo, the conditions being a ritual, the privileged status of those who can talk and their specific status define this period. The bars of prohibition are built around politics, sexuality and insanity" (Işık, 1998, p.109).

The viewer see the sexual tension between the father and the daughter in a prejudiced way, the probability that the father may not be the biological father does not affect this prejudice. According to Foucault, power, as in many other domains, shapes and reveals sexuality, also creates a continuous control mechanism to make it inescapable; sexuality is a factor with sense value. Here, sexuality appears to be both a field of power and a social taboo. In fact, it seems clear that, from the beginning, Foucault's work on sexuality was developing a dimension beyond that of power relations. It was becoming a history of the formation of subjects in not only a political but also a psychological and ethical sense. (Gutting, 2005: 92)

\section{Thou shalt not kill, thou shalt not steal}

Dekalog 5, based on the "thou shalt not kill" commandment, tells a story of crime and punishment. The film begins with the lawyer Piotr speaking; he questions justice, crime, punishment, and those who make laws; he is not sure if laws may bring justice. He defends that punishment does not prevent crime, on the contrary, that they create a path of revenge. Then, we see the central character Jacek wandering in the streets of Warsaw. He is cruel to everyone, steals 
an old woman's pigeons, and throws rocks at cars. We cannot know why he does these. He has a little girl's photo in his pocket, he goes to a photo shop and asks for an aggrandizement. He is only kind to little girls.

Waldemar is a cold, harassing taxi driver, who does not seem too good for anyone. The story unfolds with Jacek riding Waldemar's car and asking to go outside the town. Jacek stops the car somewhere and violently murders Waldemar.

The paths of Piotr and Jacek are now crossed. Jacek is charged with capital punishment for murder. According to the laws, such crime requires death penalty. Jacek calls the attorney before he dies and tells him that everything started with his sister's death. Had his sister not died, he would not have left his home, would not gone to Warsaw and committed such a murder.

After the legal proceeding, Jacek is executed brutally. We witness a death scene, as realistic as the murder scene. Therefore, the "thou shalt not kill" commandment is violated twice, in different ways.

Jacek murders someone without a cause. However, the taxi driver is not a good person himself; even though he does not do anything to deserve death, he is not someone good for anyone surrounding him, he grosses a woman out with his harassment. Jacek understands, albeit too late, that killing a man does not resolve his problems, and he regrets what he did. The viewer is sad for Jacek after his talk with the attorney, even though he committed a horrible murder, he had his reasons.

Jacek did not obey the commandment, killed someone; eventually death brought more death and Jacek himself is killed at the end.

(...) Zizek says that which is unbearable in Dekalog 5, is the second murder. The repetition of the murder by the state apparatus is also a murder and means disobedience. Kieslowski does not 
consider the repetition of death as an ordinary repetition in the rhythm of everyday life. The original power, trauma and emotional violence of the film is caused by the repetition of the murder. It does not mean that the repetition of the trauma normalizes it. The traumatic event is not normalized by the repetition, but becomes more unbearable. (Kieslowski, 2009, s.14).

The "Thou shalt not kill" commandment is shown through the price of not obeying this order. The fact that Jacek killed someone would not go unpunished. The modern institutions of "locking up" (prison, hospital, mental institution, school etc.) define the production, inspection and organization of discourse. Jacek is not only imprisoned as a criminal but he is also sentenced to death. As Jacek killed someone, the law kills Jacek. In the modern world, sick souls, criminals are labeled abnormal and punished in an institutional level.

Foucault, analyzing the punishment in ancient and modern societies, argues that the punishment is reshaped, but it should also be put under question that the courts are the decisive body. "Throughout the eighteenth century, inside and outside the legal apparatus, in both everyday penal practice and the criticism of institutions, one sees the emergence of a new strategy for the exercise of the power to punish. And \&\#39;reform', in the strict sense, as it was formulated in the theories of law or as it was outlined in the various projects, was the political or philosophical resumption of this strategy, with its primary objectives: to make of the punishment and repression of illegalities a regular function, coextensive with society; not to punish less, but to punish better; to punish with an attenuated severity perhaps, but in order to punish with more universality and necessity; to insert the power to punish more deeply into the social body" (Foucault, 1995: 82). At this point, obeying-disobeying and power reestablish themselves through the relationship between crime and punishment within a body supervised by the State. 
The Dekalog $6^{1}$ is based on the "thou shalt not commit adultery" commandment. A young guy named Tomek falls in love with a woman across the street that he is peeping in. Beyond voyeurism, Tomek lives with this woman in his inner world, eats his dinner at the same time with her, as if she is with him. Meanwhile, the woman is unaware that she's being peeped in.

Tomek who is included in the woman's life for afar, somehow makes her come to the post office that he works in and later becomes her milk distributor. Tomek, one day, admits that he has been peeping in her and he is reprimanded by the woman. The woman, who is now aware that she's being peeped in, provokes Tomek. Peeping and being peeped become a play for the woman, while it is getting dangerous for Tomek. The disappointment following his encounter with the woman will drive him to slashing his wrists. There is a mysterious relationship between the woman and Tomek. As the milk constantly spilled in the film, this relationship is also all over the place; we cannot have a full picture of it.

"[W]hen I film a scene with a bottle of milk, for example, somebody suddenly starts to draw conclusions which never crossed my mind. For me, a bottle of milk is simply a bottle of milk; when it spills, it means milk's been spilt. Nothing more. It doesn't mean the world's fallen apart or that the milk symbolizes a mother's milk, which her child couldn't drink because the mother died early, for example. It doesn't mean that to me. A bottle of spilt milk is simply a bottle of spilt milk. And that's cinema. Unfortunately, it doesn't mean anything else" (Reeve quoting Kieslowski, 2014, s.277).

Here, we witness that the woman, while having another lover, likes being peeped in and gets closer to Tomek, while this drives Tomek to suicide. The woman who allows being peeped

${ }^{1}$ Kieslowski directed A Short Film about Love in 1988 as a feature-length, then included a short-metrage version to the Dekalog. The Dekalog 6 is an abridged version of A Short Film about Love. 
as a form of adultery enjoys this situation, but it is a painful process for Tomek. Even though he attempts to die by slashing his wrists, he somehow survives through the situation he is in. At the end of the film, we understand that he got rid of these feelings and made a fresh restart.

The works of Foucault on surveillance and power are also reflected on the relationship between the woman and Tomek. The process of surveillance is a reciprocal tool of power. Tomek, who peeps, creates a field of power for himself as the other person does not know that she is being peeped in. Foucault argues that, in the modern period, we are living in a society dominated by surveillance and inspection; surveillance is a method of the State gathering information on the individual. "Docile bodies are produced through three distinctively modern means. Hierarchical observation is based on the obvious fact that we can control what people do merely by observing them. The watchtowers along city walls are a classic example. But modern power has raised the technique to a new level" (Gutting, 2005: 82). This information stems from the surveillance, categorization, recording and comparison of individuals' behaviors.

In the modern times, our bodies that we deemed to be "ours," thus private, become a resource of surveillance data. Therefore, Tomek's surveillance is a way of creating power of himself. The woman is helpless and weak against him, while in normal life, he is more vulnerable than the woman. Surveillance creates a field of power that compensates Tomek's weakness.

In the Dekalog 7, the "thou shalt not steal" commandment is shown through a child. Marjwek is impregnated by her teacher when she was 16 . Her mother, who is also the head mistress, in order to prevent a scandal, claims that the child is hers and becomes her mother. Five years later, the child knows her real mother as his sister. Marjwek wants to tell the truth to her daughter and kidnaps him. Because her mother is obsessed with the child and stole her from her own daughter. When Majka kidnaps the child, she tells her that she is her real mother. She finds the father's house, they pay him a visit. Eventually, this runaway story becomes a revenge against 
the mother. While the real father takes responsibility of the child, he believes that the runaway is not good for the child and calls the family. Majka gets caught with her daughter at train station, and her daughter runs to her grandmother, calling her mother. This is a real devastation for Majka and she runs away with the first train arriving at the station.

Zizek, in the "thou shalt not steal" commandment, argues that the stealing takes places in a symbolic order, not a material one. The real problem in stealing is not taking over somebody else's property, but violating the symbolic honestly in a latent manner (Zizek, 2009, p. 16).

In stolen property in the film is not goods, it is a living person, a child, an emotion. The Dekalog is based on the question of reference, "can you steal something that already belongs to you?" The baby that Majka gave birth to, who already belonged to her, was stolen five years ago, and she could only be a sister to her own daughter. Years later, when she kidnapped the child, she becomes the person who stole the child that belongs to her.

Majka means "mother" in Slavic languages (Zizek, 2009, p. 16). Kieslowski, in his film, does not obey the Moses' commandment, and he shows his disobedience through the woman who stole her own child. The name that Kieslowski gave to the woman shows that he considers that woman who steals the child as the real mother. Therefore, stealing is not a sin but taking what belongs to her.

Being a mother is an emotion that creates a field of power. The domination of the mother over the child happens in different periods from infancy to puberty. Majka's mother tells her granddaughter that she is her mother and takes over this field of power from Majka. Majka resists against this by kidnapping her own daughter. According to Foucault, there are also resistance fields with the fields of power and individuals creates their own resistance fields against the power. Majka creates such a field by abducting her own child and telling her the truth. Foucault says that 
resistance exists where power is, and depends power relationships on the plurality of resistance against power (Akay, 2000, p.20).

In Dekalog 8, we see Zofia, an ethics professor. One day, Elzbieta, a woman from New York, joins her class. She met Elzbieta before when she was in New York for a conference, she remembers her and invites to her class. Morality is the course subject. One of the students talk about the doctor-woman-man story that takes place in Dekalog 3. Professor says that the most important point at that story is that the child is born and stays alive. Afterwards, the invitee takes the floor and tells another story from 1943. At that period, a family who decides to save a girl child by making her Catholic changes their mind at the last minute. That is practically the death warrant for the child. However, the girl is saved by another family and survives. That girl is Elzbieta, the invitee at the class, and the parent who changed her mind is the professor, Zofia.

After class, there will surely be a confrontation. Zofia invites Elzbieta to dinner. Zofia tells her that incident was a breakpoint for her and how she regretted that. Her husband was from the resistance, and they rejected the child because they learned she was known and used by Gestapo. Days later, they realized that this was false information. This incident changed Zofia's life, maybe paved way to her becoming an ethics professor.

Zizek finds the reference to the second Dekalog during the class ironic. In the second Dekalog, the child has a chance to live because the woman gave birth to the child. The professor says the child being born is the most important part of the story. However, years ago, she did not take the chance to save a child. According to Zizek, in this Dekalog, "there is a dialectic tension between telling the truth or telling lies. Someone can lie in disguise of the truth, or tell the truth in disguise of a lie" (Zizek, 2009, p.17).

Here, power is established through discourse. Zofia gives up looking after the girl as she could be used by Gestapo, however this turns out to be false information. Zofia, as a member of 
the petty bourgeoisie, undermines defenseless Ezlbieta and deems herself qualified to decide on somebody's life using her power.

For the perception of the bourgeoisie, the power and limits of regard are crucial. Regard is a form of cultural and symbolic capital that is after economic power. The bourgeois regard views the "other" to entertain itself through the symbolic domination granted to it by the "other." It demands symbolic "power" over those inferior to it, and competes with its equals for such power (Orr, 1997, p.87). Zofia deemed the girl inferior to herself, and rejected her by the symbolic power.

\section{Passions and fathers}

The Dekalog 9 opens with Roman, an impotent man, learning that he cannot be with his wife Hanka anymore. The film, based on the commandment "thou shalt not covet neighbor's properties," narrates a story of romance, sex and love. Hanka, even though she says that romance and love can be possible without sex and passion, sleeps with another man after learning her husband's condition. The husband loses his power along with sex, and his condition pushes him into helplessness and a neverending feeling of jealousy. He becomes suspicious with the phone calls and faces the truth when he follows his wife.

“... a moral view about how to handle a situation is easily transformed into a sense that certain feelings should not be experienced. I have heard people - men and women - whose partners are having affairs say that they should not feel jealous, that the feeling itself is wrong. And I have heard people who have embarked on affairs express horror and indignation at the jealousy of their partners, as if such a reaction were not entirely predictable. If we value something and it seems that some other person might have access to that something, and might possibly take it away, then we are bound to feel all those reactions - a fear of loss, a sense of betrayal, anger and resentment and more - that go to make up what we call jealousy. Jealousy is a sign that something is valued and desired, on the whole, I think, a positive - if unpleasant —emotion"

(Craib, 2002, p. 48). 
For Roman, being cheated on, being forced to share his wife with someone else is a helpless feeling. He is impotent and physically unable to provide lust with Hanka. Yet, he is jealous. While he feels jealousy, he also thinks Hanka is right. This dilemma makes him consider death.

When Hanka realizes she loves her husband, she leaves the other man out of her life, comes clean with Roman and they decide to give their relationship another try, even adopt a child. However, when she comes across with her former lover in her vacation, her husband misunderstands the situation; Roman thinks Hanka is on vacation with her lover, and commits suicide. At the end, the misunderstanding is resolved, the man is still alive.

Kieslowski, in this Dekalog, tells a story of cheating over the "thou shalt not cover thy neighbor's wife" commandment. In the finale, as Roman and Hanka are back together, he implies that love can be possible without lust. The neighbor coveting over somebody else's wife is thus in vain. Here, there is compromise between order and obedience, the course of the film approves Moises' commandment.

In this film, the power is directly based on sex and body. As the male body loses power over the female body, the man could not bear to exist and considered suicide. Such loss of power makes it harder to exist a subject in life. According to Foucault, power shapes, reveals and supervises sex, creates a permanent supervision over it; sex is an effect with a meaning. Foucault is interested in the function of sex in society and the role of institutions and discourse in its conception, rather than what it is. Loss of power due to impotence is a reason for powerlessness, socially and personally.

In Dekalog 10, the story of Jerzy and Artur, two brothers who do not know what to do with their late father's stamp collection, is told. One of the brothers is a married man with a child, and the other is a rock star. At first, they do not know about the value of the collection, but soon after they realize it is a fortune. However, one stamp crucial to the collection is missing. This pink stamp 
is hard to find. A second-hand seller tells them he could find the stamp, but he wants a kidney from the brothers in exchange, because his 16-year-old daughter is sick. Jerzy, who does not mind living with a single kidney, donates one. However, while he is hospital, the entire collection is stolen. Both brothers first get suspicious of each other, but the real person to be suspicious about is their neighbor. They end up with a single, valuable stamp that cannot be sold but exchanged.

The film that is based on the "Thou shalt have no other gods before me" commandment, shows the neighbor in the opening scenes. He visits the brothers after their father is dead, reminds them of the father's debt and that they can pay it with the stamps. The brothers refuse to give the stamps. However, at the end, the situation shows that it may be the neighbor who stole the stamps.

Helen A. Fielding, in her article on body and films, argues that our expressions, emotions and sentiments are displayed by the body. She claims that it is possible to interpret Kieslowski movies based on this argument.

Kieslowski explores the complex ethical dilemmas that exceed daily life by using multilayered situations that do not lend themselves to simple interpretations or easy solutions.... But more importantly, the spectator is called forth by the films not simply to "spectate," but rather bodily to engage in the films themselves. (Fielding, 1998, p.536-537).

Deciding to give a kidney is a choice. Jerzy did not hesitate to give his kidney in exchange for the stamp. According to Fielding, even though Kieslowski seems to create a choice, actually he creates a situation.

Kieslowski, as he himself says, explores the individual's internal "barometer" in face of ethical decisions (Stok, 1993). What is interesting about this barometer is that it is that of an embodied subject; indeed, this film also anticipates the viewer as embodied subject. For this 
reason, Kieslowski does not simply present the ethics of whether or not the one brother should exchange his kidney for a stamp. Rather, he establishes a situation. (Fielding, 1998, p.537).

The "Thou shalt have no other gods before me" commandment is tied to the stamp collection activity in a direct way. Stamp collection is glorified. The stamp collecting activity itself is systematic. The audience, even though they have never seen the father, understands that the stamps are the father's way to communicate with the world. That is a relationship he cannot have with his sons.

According to Zizek, an ordinary activity such as stamp collecting results in giving everything, work, happiness, even a kidney (Zizek, 2009, p.9). After the funeral, two brothers having a look at the stamps share the same feeling. Their relationship with their father was always distant and limited. The father devoted himself to stamp collection, a passion that he cannot get over. Albert O Hirschman argues that there is a distance between passion and reason, and when they face off, passion wins. Because the reason succumbs to the destructiveness of passion (Hirschman, 2008, p.59).

In the tenth Dekalog, there is a price for not obeying the commandment. Glorifying stamp collection made the father distant to his children, and he could not stop the stamps from being after he was dead. Here, the disobedience against the "Thou shalt have no other gods before me" commandment is revealed through the father's relationship with the stamps. He saw stamp collection like another god that gives him happiness and motivation.

The father's passion opened a window for the sons after his death, unified the brothers who were long distant. In the scene that we saw the brothers together during the sunrise, their faces and bodies are closer. Their bodies are shining under the sunlight. Artur, in this scene, realizes something for the first time. The apartment is open to burglars' entry. Its height of a few meters is not an obstacle. While being concentrated on the stamps, they forgot about the rest, including their 
responsibilities. Fielding, who analyzes Dekalog 10 through the body, analyzes the rapprochement of two brothers accordingly. According to her, what happens is going back to the childhood without worries, and the relationship with the brother during the childhood (Fielding, 1998, p.541).

They indeed remember that they are brothers and create a bond similar to one established in the childhood. Finding the stamps after the father's death, meanwhile, disrupts the mourning.

“(...) For Freud, mourning involves a withdrawal from the outside world, and a concentration on the one who has been lost; this is accompanied by painful feelings of dejection and an inability to find a new love object. We work through mourning, with great expense of energy, by repeated reality testing and finding that the loved one really has gone.... For Klein, the loss of a loved one threatened the whole of the internal world; most basically it threatened the good internal objects that we had been able to make of our parents, a process that marks the negotiation of the infantile depressive position."

(Craib, 2002, p.16-17).

Artur and Jerzy forget about the mourning and concentrate on the stamps. When they come home back from the memorial service, it is the worth of the stamps that is important, not the mourning. Giving up mourning and focusing on the stamps to an extent that they give a kidney for a rare stamp make them closer to their late father. Therefore, stamps getting stolen may be considered to be a positive development. Otherwise, it is probable that their relationship with the stamps may be like their father's.

In the last Dekalog, a power relationship between two brothers is told. They are united by their father's death. Being brothers means a power struggle against the father. Since the father is no more, the struggle is now between the two. That power relationship does not yield a constant dominating actor, the power is alternated constantly. However, when one of the brothers gives his 
kidney, giving up a part of his body, he earns a field of power. However, throughout the Dekalog, the real power holder is not the brothers or the father, it is the stamps against which they all are powerless.

\section{Discussion}

Kieslowski's artistic concern is framed by the common themes in his films; human, its alienation, solitude, desperation, love and death. While weaknesses and pessimism are the dominating themes in his most films, he tones them down with the visual world and colors that he creates, thus portraying a dark but artistic world. In his many films, not only in the Dekalog, he incites questions on love and death. However he never proposes a solution, he discusses the questions he brings up. He set his protagonists free, and watches how people unravel, the most essential part of the human nature. The same situation takes places in the Dekalog, and we often see how the characters unravel and how a power relationship emerges when two characters enter the scene.

For Foucault, the power is an ensemble of invisible commandments, rather than a religious belief. The Dekalog is like a visual interpretation of Foucault's views on power. In Foucault's power, the invisible commandments are rather a way of interaction. Therefore, the power relationships are more important than the power itself. Power is not a mere relationship between parties, but an action of some over others. Power has effects like provocation, encouragement, limitation, facilitation or aggravation over actions. In other words, power exists as a set of actions over other sets of action.

In Kieslowski’s Dekalog, the power relationships are ways of interaction, just like Foucault says, and they become processes that drive the commandment-obedience relationship. In each film, we see the commandments disclosed to Moses. The commandment appears as the theme. The 
interactions between characters and the reactions moves the theme to another way. Sometime, the theme complies with the course of events but mostly it has no representation in today's world. The power relationships that Foucault states also shape these processes. The power relationships are shaped by the commandment-obedience relationship.

If we have to briefly sum up the Dekalog, there is a two way effect developing through the commandment-obedience-power triangle and its reflections on the characters. In the first Dekalog, Kieslowski draws a three-dimensional picture depicting science and God, and pushes his audience to questioning the relationship. He does not pick a side between science and God, he just shows the characters and how they unravel. In the Dekalog 4, he picks a bolder issue and reverses the father-daughter relationship. At that point, he overlaps Foucault's argument that the discourse is controlled in the modern society. In the Dekalog 5, there is a crime and punishment story based on killing. Kieslowski puts good and evil, dying and killing under question and criticizes the modern society's ways of punishment. In the Dekalog 6, surveillance is the theme, while it shows how condescending creates a field of power and domination through the story of an ethics professor in the Dekalog 8. In the last Dekalog, being attached to a passion appears as a rebellion against the God. The power relationship takes place between two brothers.

In a relationship between brothers, father and son or in a confrontation, the power as Foucault's moving shadow makes an impact over characters and events. In Foucault, power is not only analyzed through pressure, discipline and punishment, but also through the aspects that generate realities, domains of subject and rituals of truth (Sarup 1997, p.116). Therefore, power is analyzed first vis-à-vis the subject, and then those generated and reproduced by the power discourse. Power and subject are analyzed through a forced relationship. Hence, subject is not excluded from the power discourse, and the power discourse from those it generates. 
In the Dekalog, each subject decides for themselves and their decisions affect others. Interactions such as the punishment of the soul, forbidden word, discourse and alternating power relationships appear in the Dekalog, in different forms. While a field of power is created, the obedience-disobedience relationship is also affected.

Today, in the modern everyday life, it is very hard to abide by the Ten Commandments. Politically and economically, a lot has changed, wars took place and the ways the people consider religion and life became different. Regarding the commandment-obedience relationship, the Ten Commandments said to be disclosed to Moses do not have an equivalent in the Kieslowski's Dekalog series. Due to obligations and coincidences, the course of events takes place differently for everyone and leaves every individual with their own dilemmas.

\section{BIBLIOGRAPHY}

Akay, Ali. (2000) Foucault'ta Iktidar ve Direnme Odakları. 2.ed. Istanbul: Bağlam Yayınları.

Butler, Judith. (2004). Precarious life: The powers of mourning and violence. Verso.

Canpolat, Nesrin. (2003) Foucault. Kadife Karanlık. Istanbul: Su Yayınlar1

Craib, Ian. (2002). The Importance of Disappointment. Routledge.

Fielding, Helen A. (1998). Body Measures: Phenomenological Considerations of Corporeal Ethics. Journal of Medicine and Philosophy. Vol 23. No 5. 533-545.

Foucault, Michel (2003) Toplumu Savunmak Gerekir. Şehsuvar Aktaş (Tra.) Istanbul: YKY Yayınlar1.

Foucault, Michel (2003) İktidarın Gözü. Işık Ergüden (Tra.). Ayrıntı Yayınları. Foucault, Michel (1998) The History of Sexuality: The Will to Knowledge, London, Penguin.

Foucault, Michel (1995) Discipline and Punish: The Birth of the Prison. Trs. By. Alan Sheridan. Vintage Books, New York 
Gutting, G. (2005). Foucault: A very short introduction. Oxford University Press

Hirschman, Albert O. (2008). Tutkular ve Çıkarlar. Barış Cezar (Tra.) Istanbul: Metis Yayınları.

Işık, Emre. (1998) Beden ve Toplum Kuramı. Istanbul: Bağlam Yayınları.

Kickasola, Joseph G. (2016). Tablets of Stone, Tablets of Flesh: Synesthetic Appeal in The Decalogue. Eva Badowska, Francesca Parmeggiani (Ed.) Of Elephants and Toothaches: Ethics, Politics, and Religion in Krzysztof Kieslowski's Decalogue (p.30-50). Fordham University Press.

Kieslowski, Krzsytof. (Director). (1989-1990). Dekaloglar Series [Film] Turkey: Birfilm Company.

Larrain, Jorge.(1995) İdeoloji ve Kültürel Kimlik. Neşe Nur Domaniç (Tra.). Istanbul: Sarmal Yayınları.

Le Breton, David. (2005) Acının Antropolojisi. İsmail Yerguz (Tra.) Istanbul: Sel.

Lefebvre, Henry.(2007) Modern Dünyada Gündelik Hayat. 2.ed. Işın Gürbüz. (Tra.) Istanbul: Metis.

Orr, John. (1997) Sinema ve Modernlik. Ayşegül Bahçıvan. (Tra.) Ankara: Ark Yayınları

Reeve, C.D.C (2014). Lessons in Looking. Susan Wolf and Cristopher Grau. (Ed.) Understanding Love: Philosophy, Film and Fiction. (s.272-287). USA: Oxford University Press.

Sarup, Madan (1997) Post Yapısalcılık ve Postmodernizm, A. Baki Güçlü (Tra.) Ankara: Ark Yayınevi.

Taşçıyan, Alin. (1997). Krzysztof Kieslowski Üzerine Öznel Bir Deneme. Kitle Yayınları (Ed.) Avrupalı Yönetmenler. (s.107-119). Istanbul: Kitle.

Zizek, Slavoj. (2008). Kieslowski: Ya da Maddeci Teoloji. Sabri Gürses (Tra.) Istanbul: Encore. 